\title{
PENGARUH STIMULASI WICARA DALAM PEMBELAJARAN TERHADAP KEMAMPUAN BERBAHASA ANAK TUNARUNGU USIA DINI DI TK TUNARUNGU SUSHRUSA
}

\author{
Luh Ade Vivi Anggraeni ${ }^{1}$, Luh Ayu Tirtayani ${ }^{2}$, I Wayan Sujana ${ }^{3}$ \\ 1,2,3Jurusan Pendidikan Dasar \\ Universitas Pendidikan Ganesha \\ Singaraja, Indonesia \\ e-mail: vivi.anggraeni1997@gmail.com ${ }^{1}$, ayu.tirtayani@undiksha.ac.id ${ }^{2}$, \\ wayan.sujana@undiksha.ac.id ${ }^{3}$
}

\begin{abstract}
Abstrak
Penelitian ini bertujuan untuk mengetahui pengaruh stimulasi wicara dalam pembelajaran terhadap kemampuan berbahasa anak tunarungu usia dini di TK Tunarungu Sushrusa Denpasar Tahun Ajaran 2018/2019. Penelitian ini merupakan penelitian pre-eksperimental one group pretest-posttest design dengan pendekatan pembelajaran kuantitatif. Sampel dalam penelitian ini adalah anak tunarungu di TK Tunarungu Sushrusa Denpasar yang berjumlah 11 anak. Instrumen yang digunakan dalam penelitian ini adalah pedoman observasi berupa kisi-kisi kemampuan berbahasa anak tunarungu sebanyak 9 butir. Berdasarkan hasil penelitian, data kemampuan berbahasa anak tunarungu menunjukan nilai rata-rata pre-test sebesar 43,18 , sedangkan nilai rata-rata post-test sebesar 70,63, dan diperoleh nilai thitung $=28,29$ berdasarkan taraf signifikansi $5 \%$ dengan $(\mathrm{dk}=10)$, maka diperoleh tabel $=2,228$. Sehingga data kemampuan berbahasa anak tunarungu mununjukan bahwa thitung $>$ tabel. Maka dapat disimpulkan bahwa, stimulasi wicara berpengaruh terhadap kemampuan berbahasa anak tunarungu di TK Tunarungu Sushrusa Denpasar Tahun Ajaran 2018/2019.
\end{abstract}

Kata kunci: Anak Tunarungu, Kemampuan Berbahasa, Stimulasi Wicara

\begin{abstract}
The purpose of this study is to determine the effect of speech stimulation in learning on the language skills of deaf children at TK Tunarungu Sushrusa Denpasar in academic year 2018/2019. This study is pre-eksperimental one group pretest-posttest design with quantitative learning approach. The Subject of this study are 11 deaf children in TK Tunarungu Sushrusa Denpasar. The instrument used in this study is an obsrevation guidline in form of 9 items of language skills of deaf children. The results of this study, shows the pre-test average value is 43,18 , while the post-test value is 70,63 , and the value of thitung $=28,29$ at $5 \%$ significance level $(\mathrm{dk}=10)$, obtained tabel $=2,228$, there is significant difference, so the data on the language skills of deaf children shows that thitung $>$ tabel. It can be concluded that, speech stimulation affects the language skills of deaf children at TK Tunarungu Sushrusa Denpasar in academic year 2018/2019.
\end{abstract}

Keywords: Deaf Children, language skills, speech stimulation. 


\section{PENDAHULUAN}

Pendidikan adalah salah satu jembatan untuk mewujudkan cita-cita nasional yaitu mencerdaskan kehidupan bangsa, karena pendidikan memberikan bimbingan dan arahan kepada peserta didik untuk mencapai tingkat kedewasaan, berkembangnya kemampuan anak usia dini untuk menciptakan kemandirian dan kesejahteraan pada anak, supaya mampu mandiri dan menampilkan individualitasnya sebagai manusia terdidik. Menurut Maimum (2016), pendidikan adalah salah satu wadah untuk menjadikan manusia untuk berprilaku sopan. Pendidikan bisa dilakukan dimana saja misalnya di dalam keluarga karena keluarga merupakan lembaga yang tidak boleh dikesampingkan, dari anak baru lahir keluargalah yang memberi anak pendidikan pertama kali, maka dari itu lingkungan keluarga diharapkan mampu membangun karakter pada diri anak serta mampu memberi ilmu pengetahuan kepada anak.

Setiap warga negara harus dan wajib mengikuti jenjang pendidikan, baik jenjang pendidikan anak usia dini, pendidikan dasar, pendidikan menengah maupun tinggi. Kebanyakan anak-anak Indonesia dalam memulai proses masuk ke lembaga pendidikan, mengabaikan pendidikan anak usia dini, padahal untuk membiasakan diri dan mengembangkan pola pikir anak pendidikan sejak usia dini mutlak diperlukan.

Taman kanak-kanak merupakan salah satu pendidikan anak usia dini yang memiliki peran sangat penting untuk mengembangkan kepribadian dan keterampilan anak serta mempersiapkan anak memasuki jenjang pendidikan selanjutnya. Menurut Asmariani (2016), pendidikan anak usia dini (PAUD) merupakan salah satu bentuk penyelenggaraan pendidikan yang menitikberatkan pada peletakan dasar kearah pertumbuhan dan perkembangan fisik. Tujuan pendidikan Taman Kanak-Kanak (TK) adalah membantu berbagai potensi yang meliputi nilai agama, moral, kognitif, fisik motorik, bahasa dan sosial emosional untuk siap memasuki jenjang pendidikan berikutnya. TK harus mampumenciptakan lingkungan yang aman dan nyaman bagi anak karena lingkungan sebagai wahana tumbuh kembang anak. Pelaksanaan pembelajaran di TK yaitu melalui bermain sambil belajar, karena bermain merupakan hal yang menyenangkan dan mengasikkan untuk diri anak dan melalui bermain anak dapat mengeksplorasi dirinya sendiri.

PAUD tidak hanya diterapkan bagi anak-anak normal, ABK juga berhak memperoleh pendidikan sejak dini pada lembaga pendidikan formal.Walaupun seseorang termasuk ke dalam ABK dan terbatas di dalam menjalankan aktivitasnya di kehidupan sehari-hari, bukan berarti mereka tidak boleh mendapatkan sentuhan pendidikan. Menurut Silayusa (2015), ABK adalah anak dengan karakteristik khusus yang berbeda dengan anak pada umumnya tanpa selalu menunjukan pada ketidakmampuan mental, emosi atau fisik. ABK disini bukan saja mereka yang memiliki kelainan fisik, sosial, emosional, dan intelektual saja, melainkan mereka yang memiliki potensi kecerdasan dan bakat istimewa juga berhak memperoleh pendidikan layanan khusus.

Layanan pendidikan lain untuk ABK dengan jenis-jenis kecacatannya adalah Sekolah Luar Biasa (SLB). Menurut Bayu (2015), SLB adalah sebuah lembaga pendidikan formal yang melayani pendidikan bagi anak-anak berkebutuhan khusus. Dari SLB inilah anak-anak yang berkebutuhan khusus akan terbantu dan menjadi pribadi yang baik dan memiliki pengetahuan sesuai dengan karakteristik serta anak akan belajar lebih mandiri mampu berinteraksi dengan lingkungan serta tidak merasa diasingkan. Pelaksanaan SLB memiliki spesialisasi khusus sesuai dengan hambatan ABK yang, SLB A untuk tunanetra. SLB B untuk tunarunggu, SLB C untuk tunagrahita, SLB D untuk tunadaksa, SLB E untuk tunalaras dan SLB G untuk cacat ganda.

SLB B merupakan sekolah yang diperuntukkan bagi anak yang memiliki kekurangan dalam indra pendengaran atau tunarungu. Menurut Rahmaniar (2015), anak tunarungu adalah anak yang mengalami kehilangan kemampuanmendengar yang disebabkan karena kerusakan atau tidak berfungsinya sebagian atau seluruh alat pendengarannya sehingga anak mengalami hambatan dalam hal berbicara. Anak tunarungu tidak berbeda dengan anak normal lainnya kalau dilihat secara fisik, orang tidak akan mengertahui bahwa anak tersebut tunarunggu jika belum mengajak anak tersebut berkomunikasi. 
Kemampuan berbahasa adalah kecakapan, ekspresi, kekayaan ucapan dan perasaan manusia melalui bunyi yang digunakan untuk bekerjasama, berinteraksi dan mengidetifikasi diri dalam percakapan yang baik. Kemampuan berbahasa juga merupakan aspek penting, tetapi tidak semua anak mampu menguasai ini, ketidakmampuan anak berkomunikasi secara baik karena keterbatasan kemampuan menangkap pembicaraan anak lain atau tidak mampu menjawab dengan benar. Menurut Safitri ( 2017). Kemampuan berbahasa merupakan indikator seluruh perkembangan anak. Kurangnya stimulasi akan dapat menyebabkan gangguan bicara dan berbahasa bahkan gangguan ini dapat menetap.

Berdasarkan hasil observasi yang dilakukan pada tanggal 21 februari 2019 dikatakan bahwa TK Tunarungu Sushrusa Denpasar berjumlah 11 anak. Permasalahan yang ditemukan akibat dari terhambatnya perkembangan berbahasa anak menyebabkan anak tunarungu akan mengalami kesulitan dalam hal berkomunikasi. Kesulitan berkomunikasi yang dialami anak tunarungu, mengakibatkan mereka memiliki kosakata yang terbatas, sulit mengartikan ungkapanungkapan bahasa yang mengandung kiasan, sulit mengartikan kata-kata abstrak, serta kurang menguasai irama, gaya bahasa dan juga kesulitan dalam pemahaman bacaan materi pelajaran karena miskin bahasa/kosa kata. Dengan demikian anak tunarungu perlu mengembangkan kemampuan berbahasa dasar yang dimilikinya.

Untuk mengembangkan kemampuan berbahasa pada anak tunarungu salah satunya adalah denganmenggunakan stimulasi wicara. Pemberian stimulasi pada anak adalah rangsangan atau dorongan akan mempercepat perkembangan anak itu sendiri, maka dari itu diharapkan dengan memberi stimulasi wicara dapat membantu mempermudah anak dalam mengembangkan kemampuan yang ada pada diri anak. Stimulasi wicara atau yang sering juga disebut dengan terapi wicara merupakan suatu usaha atau perbaikan pembicaraan terhadap mereka yang mengalami kelainan pembicaraan.

Menurut Salis (2016), stimulasi wicara diberikan untuk membantu anak tunarungu yang mengalami gangguan artikulasi (ketidakjelasan dalam berbicara). Stimulasi wicara juga yang memberi pengalaman kepada anak agar anak bisa membaca ekspresi muka dan mimik disini di harapkan anak mampu berbicara tanpa perlu menggunakan bahasa isyarat. Tujuan dari stimulasi wicara ini adalah sebagai suatu usaha perbaikan pembicaraan terhadap individu yang mengalami gangguan dalam bahasa dan bicara dengan cara bagaimana anak dapat mengeluarkan ide-ide yang ada dalam bentuk kata-kata serta penguasaan bahasa. Stimulasi wicara bukan hanya mengajarkan tentang vokalisasi saja, tetapi juga melatih anak untuk paham perintah, melatih kontak mata agar tetap fokus, melatih kesabaran anak dalam menunggu bermain dan melatih anak dalam menuntaskan atau menyelesaikan aktivitasnya.

Berdasarkan uraian latar belakang penelitian, maka dilakukan penelitian berjudul "Pengaruh Stimulasi Wicara Dalam Pembelajaran Terhadap Kemampuan Berbahasa Anak Tunarungu Usia Dini Di TK Tunarungu Sushrusa Denpasar Tahun Ajaran 2018/2019".

Kemampuan berbahasa adalah suatu kemampuan memilih bunyi-bunyi bahasa (berupa kata, kalimat, tekanan dan nada) secara tepat serta memformulasikannya secara tepat pula guna menyampaikan pikiran, perasaan, gagasan, fakta, perbuatan dalam suatu konteks komunikasi (Fitri, 2012). Sedangkan Menurut Yuliana (2017),kemampuan berbahasa merupakan kesanggupan atau kecakapan anak untuk berkomunikasi dengan orang lain di lingkungannya, yang mendorong perkembangan kognitif dan melatih sosio-emosional melalui interaksi sosial. Apabila anak mengalami hambatan atau keterlambatan dalam berbahasa, maka akan berdampak pada psikologis anak. Ketidakmampuan anak berkomunikasi secara baik karena keterbatasan kemampuan menangkap pembicaraan anak lain atau tidak mampu menjawab dengan benar.

Masalah perkembangan bahasa terkait dengan terbatasnya pembendaharaan kata anak, gangguan artikulasi seperti sulit mengucapkan huruf $r, s, y, ~ I, f, z$, atau c. dapat disimpulkan bahwa pengertian kemampuan berbahasa adalah kecakapan, ekspresi, kekayaan ucapan dan perasaan manusia melalui bunyi yang digunakan untuk bekerjasama, berinteraksi dan mengidetifikasi diri dalam percakapan yang baik. Kemampuan berbahasa juga merupakan aspek 
penting, tetapi tidak semua anak mampu menguasai ini, ketidakmampuan anak berkomunikasi secara baik karena keterbatasan kemampuan menangkap pembicaraan anak lain atau tidak mampu menjawab dengan benar.

Fungsi Kemampuan Berbahasa dapat digunakan sebagai alat komunikasi yang berbentuk suara atau bahasa lisan, ada beberapa fungsi bahasa (Sardjono, 2014:7) antara lain sebagai berikut.

a) Bahasa sebagai alat komunikasi

Hubungan antara manusia merupakan kebutuhan hidup mereka maka dari itu bahasa sebagai alat komunikasi untuk manusia berinteraksi dengan sesamanya.

b) Bahasa sebagai alat penolong

Bahasa juga sebagai alat penolong untuk memproduksikan apa yang telah diketahui, menolong untuk menyatakan, fikiran atau perasaan dan pengetahuan serta ilmu-ilmu yang telah dimiliki juga untuk menolongmenjelaskan hal-hal yang abstrak menjadi konkret.

c) Bahasa sebagai wadah pengantar makna

Rangsangan yang diterima anak sejak lahir, mengucapkan sesuatu, menimbulkan tanggapan atau reaksi tertentu pada orang lain. Karena pengalaman ia juga mengetahui bahwa ucapan seseorang selalu dihubungkan dengan benda atau situasi tertentu.

Perkembangan bahasa sebagai salah satu dari kemampuan dasar yang harus dimiliki anak. Dengan bahasa anak dapat menyampaikan maksud, tujuan dan pemikiran, maupun perasaannya pada orang lain. Aspek-aspek yang berkaitan dengan perkembangan bahasa anak usia dini (Rosmiyati, 2017) sebagai berikut.

a) Kosa Kata

Kosa kata adalah kumpulan kata yang merupakan bagaian dari bahasa dan digunakan untuk menyusun kalimat. Kosa kata anak akan berkembang dengan pesat seiring dengan perkembangan anak dan pengalamannya berinteraksi dengan lingkungan disekitarnya.

b) Tata Bahasa

Walaupun anak belum memahami tata bahasa melalui komunikasi dengan seseorang yang berada di lingkungannya, anak secara tidak langsung belajar tata bahasa yang baik. Misalnya: "Nina menanam pohon", bukan "pohon Nina menanam".

c) Semantik (penggunaan kata)

Semantik maksudnya penggunaan kata yang tepat untuk menyatakan tujuan anak. Anak sudah dapat mengekspresikan keinginannya atau penolakan dengan menggunakan kata atau kalimat yang tepat. Misalnya: "tidak mau" untuk menyatakan penolakan.

d) Fonem (satuan bunyi kecil yang membedakan kata)

Anak dalam usia ini sudah mampu merangkaikan bunyi yang didengarnya menjadi satu kata yang mengandung arti. misalnya I, b, u menjadi ibu.

Masa pemerolehan bahasa anak tunarungu tidak dapat dilalui seperti halnya anak yang bisa mendengar. Keterlambatan perkembangan pada awal kemampuan berbahasa dapat mempengaruhi berbagai hal dalam kehidupan sehari-hari. Seperti mempengaruhi kehidupan sosial anak, menimbulkan kesulitan pada saat belajar, serta hambatan dalam bekerja kelak.

Menurut Soemantri (2012) menyatakan bahwa perkembangan bahasa anak tunarungu sebagai berikut. "perkembangan kemampuan bahasa dan komunikasi anak tunarungu terutama yang tergolong tunarungu total tentu tidak mungkin untuk sampai pada penguasaan bahasa melalui pendengarannya, melainkan harus melalui penglihatan dan memamfaatkan sisa pendengarannya".

Faktor Yang Mempengaruhi Perkembangan Bahasa Pada Anak Usia Dini Dalam kehidupan perkembangan anak, banyak faktor yang dapat mempengaruhi jalannya perkembangan anak. Mulai dari perkembangan tubuh anak, hingga faktor perkembangan bahasa anak. Yang biasanya mengalami permasalahan atau kendala sehingga, menjadikan anak mengalami keterlambatan komunikasi pada umumnya. Menurut Masitah (2016), ada beberapa faktor yang mempengaruhi perkembangan bahasa anak antara lain yaitu.

a) Faktor Kesehatan

Kesehatan merupakan faktor yang sangat mempengaruhi perkembangan bahasa anak, terutama pada usia awal kehidupannya. Apabila pada usia dua tahun pertama, anak 
mengalami sakit terus-menerus, maka anak tersebut cenderung akan mengalami kelambatan atau kesulitan dalam perkembangan bahasanya. Oleh karena itu, untukperkembangan bahasa anak secara normal, orangtua perlu memperhatikan kondisi kesehatan anak. Upaya yang dapat ditempuh adalah dengan cara memberikan air susu ibu (ASI), makanan yang bergizi, menjaga kebersihan tubuh anak atau secara rutin memeriksakan anak ke dokter atau ke puskesmas.

b) Inteligensi

Perkembangan bahasa anak dapat dilihat dari tingkat inteligensinya. Anak yang perkembangan bahasanya cepat, pada umumnya mempunyai inteligensi normal atau di atas normal.

c) Keadaan Sosial Ekonomi

Anak dari kelompok yang keadaan sosial ekonominya tinggi akan lebih mudah belajar berbicara ketimbang anak dari kelompok yang sosial ekonominya lebih rendah. Penyebab utamanya adalah bahwa anak dari kelompok lebih tinggi lebih banyak didorong untuk lebih berbicara dan lebih banyak dibimbing untuk melakukannya.

d) Jenis Kelamin

Dibandingkan dengan anak perempuan, anak laki-laki lebih tertinggal dalam belajar berbicara. Itu di sebabkan karena pada setiap jenjang umur, kalimat yang di ucapkan oleh anak laki-laki lebih pendek, kosakata yang diucapkan lebih sedikit, serta cara pengucapannya kurang tepat ketimbang anak perempuan, maka dari itu anak perempuan jadi lebih cepet dalam berbicara dari pada anak laki-laki.

e) Hubungan Keluarga

Hubungan ini dimaknai sebagai proses pengalaman berinteraksi dan berkomunikasi dengan lingkungan keluarga terutama dengan orangtua yang mengajar, melatih dan memberikan contoh berbahasa kepada anak.

Perkembangan Bahasa pada Anak Tunarunggu, Perkembangan bahasa padaanak terjadi dari aktivitas mendengar, melihat, dan meniru orang dewasa disekitar mereka. Bahasa digunakan untuk mengajarkan anak tentang sesuatu. Anak memperkaya kosa katanya melalui pengulangan. Mereka sering mengulangi kosa yang baru dan unik sekalipun mereka belum mengetahui artinya. Menurut Pebriana (2017), perkembangan bahasa pada anak usia dini merupakan salah satu faktor yang memepengaruhi perkembangan kognitif anak.

Semakin anak tumbuh dan berkembang serta mulai mampu memahami lingkungan maka perkembangan bahasa anak pun semakin berkembang dari tingkat yang sederhana menuju tingkat yang paling kompleks. Perkembangan bahasa sangat dipengaruhi oleh faktor lingkungan, karena anak mempemerolehan bahasa itu sendiri secara tidak langsung melalui lingkungan sekitar.

Masa pemerolehan bahasa anak tunarungu tidak dapat dilalui seperti halnya anak yang bisa mendengar. Keterlambatan perkembangan pada awal kemampuan berbahasa dapat mempengaruhi berbagai hal dalam kehidupan sehari-hari. Seperti mempengaruhi kehidupan sosial anak, menimbulkan kesulitan pada saat belajar, serta hambatan dalam bekerja kelak.

Pemerolehan bahasa anak yang mendengar berawal dari adanya pengalaman atau situasi bersama antara bayi dan ibunya atau orang lain yang berarti dalam lingkungan terdekatnya. Melalui pengalaman tersebut, anak 'belajar' menghubungkan pengalaman dan lambang bahasa yang diperoleh melalui pendengarannya. Proses ini merupakan dasar berkembangnya bahasa batini (inner language). Setelah itu, anak mulai memahami hubungan antara lambang bahasa dengan benda atau kejadian yang dialaminya sehingga terbentuklah bahasa reseptif anak. Dengan kata lain anak memahami bicara lingkungannya (bahasa reseptif auditori). Setelah bahasa reseptif auditori terbentuk, anak mulai mengungkapkan diri melalui kata-kata sebagai awal kemampuan bahasa ekspretif auditoria tau berbicara, meskipunpada dasarnya perkembangan kearah bicara muncul lebih dini lagi, yaitu dengan adanya masa meraban.

Kemampuan itu semua berkembang melalui pendengarannya (auditori). Setelah anak memasuki usia sekolah, pengelihatannya berperan dalam perkembangan bahasa melalui kemampuan membaca (bahasa reseptif visual) dan menulis (bahasa ekspresif visual). Berdasarkan proses pemerolehan bahasa pada anak mendengar, mengembangkan pola tersebut pada anak tunarungu. Berhubung pada masa itu teknologi pendengaran belum berkembang, maka 
anak tunarungu tidak dipandang atau kurang memungkinkan memperoleh bahasa melalui visual atau taktil kinestetik, atau kombinasi keduanya. Dengan demikian tersedia tiga alternatif, yaitu: isyarat, membaca, dan membaca ujaran.

Media membaca ujaran merupakan pilihan yang tepat dibanding isyarat dan membaca. dengan kemajuan teknologi pendengaran saat ini, maka sisa pendengarannya dapat dioptimalkan untuk menstimulasi anak tunarungu dalam perolehan bahasa. Kita dapat melatih anak tunarungu untuk menghubungkan pengalaman yang diperolehnya dengan gerak bibir dan mimik pembicara. Bagi anak tunarungu yang menggunakan alat bantu dengar, dapat menghubungkannya dengan lambang bunyi bahasa (lambang auditori).

Setelah itu, anak tunarungu mulai memahami hubungan antara lambang bahasa (visual \& auditori) dengan benda atau kejadian sehari-hari, sehingga terbentuklah bahasa reseptif visual atau auditori. Sama halnya seperti anak mendengar, kemampuan bahasa ekspresif (bicara) baru dapat dikembangkan setelah memiliki kemampuan bahasa reseptif. Selanjutnya anak tunarungu dapat mengembangkan kemampuan bahasa reseptif visual (membaca) dan bahasa ekspresif visual (menulis). Demikian perilaku bahasa verbal yang dapat terjadi pada anak tunarungu.

Pada umumnya, anak tunarungu memasuki sekolah kurang memiliki kemampuan berbahasa verbal, berbedadengan anak mendengar yang memasuki sekolah setelah memperoleh bahasa. Oleh karena itu, dalam pendidikan anak tunarungu, proses pemerolehan bahasanya diberikan di sekolah melalui layanan khusus. Layanan pemerolehan bahasa tersebut menekankan pada percakapan, seperti halnya percakapan yang terjadi antara anak mendengar dengan ibunya atau orang terdekatnya dalam pemerolehan bahasa, dengan memperhatikan sensori yang dapat diberikan stimulasi.

Percakapan merupakan kunci perkembangan bahasa anak tunarungu Oleh karena itu, guru SLB B dapat membantu anak tunarungu belajar bahasa dari masa prabahasa menuju purnabahasa melalui percakapan dan bersifat alamiah.

Stimulasi adalah rangsangan atau dorongan akan mempercepat perkembangan anak itu sendiri, maka dari itu diharapkan dengan memberi stimulasi wicara dapat membantu mempermudah anak dalam mengembangkan kemampuan yang ada pada diri anak. menurut Urdang (dalam Sardjono:147), stimulasi wicara adalah suatu usaha perbaikan pembicaraan dengan jalan memberikan kebiasaan latihan percakapan yang baik. Hal ini merupakan upaya untuk tindakan dalam mengucapkan bunyi-bunyi bahasa dalam rangkaian kata-kata agar dimengerti oleh orang yang mengajak/diajak bicara.Melalui stimulasi wicara ini diharapkan adanya perkembangan bahasa pada anak tunarunggu, dengan dipilihnya metode pembelajaran yang tepat. Tujuan dari stimulasi wicara yaitu membantu memperlancar ekspresi jiwa, menanggapi perasaan dan agar anak memfungsikan alat-alat bicaranya yang kaku, dengan harapan anak bisa memfungsikan alat bicaranya dengan baik. Dapat disimpulkan bahwa stimulasi wicara adalah suatu usaha untuk membantu seseorang agar dapat mengekspresikan ide-ide atau pikiran, mengucapkan bunyi atau suara dan mengerti perkataan orang lain. Pada anak usia dini, kemampuan berbahasa pada anak usia dini meliputi kosakata, tata bahasa dan lainnya lagi.

Tujuan penerapan stimulasi wicara ini untuk meningkatkan kemampuan bahasa dan bicara terutama produksi bahasa dengan cara bagaimana anak dapat mengeluarkan ide yang ada dalam bentuk kata-kata, serta perluasan penguasaan berbahasa. Secara umum stimulasi wicara bertujuan agar anak tunarungu (Wasita, 2013: 45).

a) Memiliki pengetahuan, keterampilan, dan sikap untuk mengucapkan bunyi bahasa Indonesia

b) Memiliki pengetahuan dan keterampilan untuk mengemudikan alat ucap, demi perbaikan dan mutu bicaranya

c) Senang menggunakan cara bicara dalam komunikasi dengan orang lain

d) Memiliki keterampilan wicara yang jelas

e) Senang melakukan evaluasi dan memperbaiki kesalahan serta berusaha meningkatkan kemampuan bicaranya.

Jadi tujuan dari stimulasi wicara bukan hanya mengajarkan tentang vokalisasi saja, tetapi juga melatih anak untuk paham perintah, melatih kontak mata agar tetap fokus, melatih kesabaran anak dalam menunggu dan melatih anak dalam menuntaskan atau menyelesaikan aktivitasnya. 
Adapun langkah-langkah yang bisa digunakan dalam pemberian stimulasi wicara menurut Sardjono (2014) yaitu sebagai berikut.

a) Breating exercise. Latihan untuk mengatur pernafasan yang baik untuk anak. Latihan ini bisa dilakukan dengan cara meniup lilin atau balon.

b) Latihan artikulasi. Melatih gerak dari organ artikulasi seperti gerak lidah, bibir, rahang. Melatih produk bunyi bahasa dimulai dari produk bunyi bahasa yang paling mudah, misalnya pada saat latihan artikulasi anak bisa mengucapkan huruf vokal agar suara yang dikeluarkan anak lebih jelas.

c) Latihan bahasa. Melatih menangkap pembicaraan orang lain,

d) Latihan phonasi. Pada latihan ini agar anak dapat memproduksi suara yang baik dan mengembangkan fungsi dari pita suara, dengan cara mendengar produksi suara yang dikeluarkan oleh anak. Ketepatan kata yang dikeluarkan anak akan memproduksi suara yang jelas.

\section{METODE}

Rancangan dalam penelitian ini menggunakan pendekatan kuantitatif dengan metode penelitian eksperimen. Penelitian ini tergolong Pre-Eksperimental Design. Desain eksperimen yang digunakan yaitu One Group Pretest-Posttest Design.

\begin{tabular}{|lll|}
\hline $\mathrm{O}_{1}$ & $\mathrm{X}$ & $\mathrm{O}_{2}$ \\
\hline
\end{tabular}

(Sugiyono, 2017: 111)

Keterangan:

$\mathrm{O}_{1}=$ Nilai Pretest kemampuan berbahasa anak TK Tunarungu Sushrusa sebelum perlakuan

$\mathrm{X}=$ Perlakuan (treatment) dengan stimulasi wicara

$\mathrm{O}_{2}=$ Nilai posttest kemampuan berbahasa anak TK Tunarungu Sushrusa setelah perlakuan.

Pemberian treatmen berupa stimulasi wicara yang dilakukan di TK Tunarungu Sushrusa. Pre-test dilakukan untuk mengetahui kesetaraan anak dengan menganalisis nilai pre-test yang diberikan kepada anak yang mencakup kemampuan berbahasa anak. post-test dilakukan pada akhir penelitian setelah diberikan perlakuan untuk mendapatkan hasil kemampuan berbahasa anak di TK Tunarungu Sushrusa Denpasar. Dalam penelitian ini yang diperhitungkan adalah skor pre-test dan skor post-test, haltersebut dikarenakan pada penelitian ini bertujuan untuk mengetahui pengaruh dari stimulasi wicara terhadap kemampuan berbahasa anak.

Populasi dalam penelitian ini adalah seluruh anak di TK Tunarungu Sushrusa Denpasar yang berjumlah 11 anak. Menurut Sugiyono (2017: 117) populasi adalah wilayah generalisasi yang terdiri atas obyek atau subyek yang mempunyai kualitas dan karakteristik tertentu yang diterapkan oleh peneliti untuk dipelajari dan kemudian ditarik kesimpulannya".

Data yang diperlukan dalam penelitian ini adalah data terkait kemampuan berbahasa anak, dalam penelitian ini diperoleh melalui teknik observasi. Langkah ini sangat penting karena data yang dikumpulkan nanti akan digunakan dalam menguji hipotesis. Maka teknik pengumpulan data harus disesuaikan dengan data yang diperlukan.

Instrumen penelitian dibuat dalam bentuk kisi-kisi kemampuan berbahasa, tetapi sebelum menerapkan kisi-kisi instrumen dilakukan uji validitas konstruk. Validitas konstruk yang menyangkut dengan isi dan format instrumen. Validitas konstruk berkenaan dengan ketepatan instrumen dalam suatu variabel yang akan diukur, serta ketepan format instrumen. Validitas konstruk terlebih dahulu aakan diuji oleh Judgement (dosen penguji) dan kepala TK di tempat penelitian. 
Untuk menganalisa data kemampuan berbahasa anak yang bersifat kuantitatif digunakan statistik uji t. sebelum dilakukan uji hipotesis terlebih dahulu menggunakan uji prasyarat analisis yaitu uji normalitas sebaran data yang dimaksud untuk mengetahui dapat atau tidaknya melakukan uji hipotesis melakukan uji hipotesis untuk mengetahui sebaran data skor nilai kemampuan berbahasa berdistribusi normal atau tidak sehingga dapat menentukan teknik analisis datanya. Kriteria pengujian adalah jika $t_{\text {hitung }}<t_{\text {tabel }}$ maka $\mathrm{H}_{0}$ diterima (gagal ditolak) yang berarti data berdistribusi normal. Sedangkan taraf sigifikansinya 5\% dan derajat kebebasannya $n-1$.

\section{HASIL DAN PEMBAHASAN}

Berdasarkan hasil mean atau rerata nilai kemampuan berbahasa anak sebelum dibelajarkan diberikan stimulasi wicara yaitu 43,18, sedangkan nilai mean atau rerata nilai kemampuan berbahasa setelah dibelajarkan dengan stimulasi wicara yaitu 70,63. Hasil data tersebut menunjukkan bahwa, kemampuan berbahasa anak sesudah dibelajarkan dengan stimulasi wicara memiliki rata-rata yang lebih tinggi dibandingkan dengan hasil sebelum dibelajarkan dengan stimulasi wicara. Hasil uji normalitas data pre-test, dapat diperoleh Chi Kuadrat hitung $\left(\mathrm{X}^{2}\right.$ hitung $\left.=1,39\right)$ kemudia nilaitersebut dibandingkan dengan Chi Kuadrat tabel $\left(\mathrm{X}^{2}\right.$ tabel $=11,07)$. hal ini menunjukan bahwa $X^{2}$ hitung $<X^{2}$ tabel berarti data pre-test kemampuan berbahasa berdistribusi normal. Berdasarkan uji normalitas data post-test, diperoleh Chi Kuadrat hitung $\left(X^{2}\right.$ hitung $\left.=2,99\right)$ kemudian nilai tersebut dibandingkan dengan Chi Kuadrat tabel $\left(X^{2}\right.$ tabel $\left.=11,07\right)$ hal ini menunjukan bahwa $X^{2}$ hitung $<X^{2}$ tabel berarti data kemampuan berbahasa data post-test berdistribusi normal.

Tabel 1.

Rekapitulasi Kemampuan Berbahasa Anak Tunarungu di TK Tunarungu Sushrusa Denpasar Tahun Ajaran 2018/2019

\begin{tabular}{lclc}
\hline \multicolumn{1}{c}{ Hasil Analisis } & Pretest & \multicolumn{1}{c}{ Hasil Analisis } & Posttest \\
\hline Mean & 43,18 & Mean & 70,63 \\
Minimum & 28 & Minimum & 53 \\
Maksimum & 58 & Maksimum & 83 \\
Rentangan & 31 & Rentangan & 31 \\
Banyak Kelas & 4 & Banyak Kelas & 4 \\
Panjang Kelas & 8 & Panjang Kelas & 8 \\
\hline
\end{tabular}

Berdasarkan hal tersebut, maka uji statistic yang digunakan dalam penelitian ini adalah uji t dengan menggunakan rumus uji varians. Setelah diperhitungkan selesai kemudian dilakukan uji signifikan yaitu dengan cara membandingkan antara thitung yang diperoleh dan ttabel. Dengan kriteria jika harga thitung < dari harga ttabel, maka $\mathrm{HO}$ diterima dan Ha ditolak, dan jika thitung > ttabel maka $\mathrm{HO}$ diolak dan Ha diterima. Pada taraf signifikansinya $5 \%$ dengan $\mathrm{dk}=\mathrm{n}-1$. Dari data tersebut menunjukan thitung yang diberikan stimulasi wicara memiliki rata-rata yang lebih tinggi sebelum dibelajarkan dengan stimulasi wicara. Dari hasil analisis uji hipotesis yang dilaksanakan diperoleh hasil yang disajikan pada tabel 1 . 


\section{PENUTUP}

Berdasarkan hasil penelitian yang diperoleh dapat disimpulkan bahwa terdapat pengaruh stimulasi wicara terhadap kemampuan berbahasa anak tunarungu. Hasil analisis data nilai mean atau rerata nilai kemampuan berbahasa sebelum menggunakan stimulasi wicara yaitu $\bar{X}=$ 43,18 sedangkan nilai mean atau rerata nilai anak yang sudah dibelajarkan menggunakan stimulasi wicara yaitu $\bar{X}=70,63$. Data tersebut menunjukan bahwa kemampuan berbahasa anak tunarungu yang dibelajarkan sesudah menggunakan stimulasi wicara memiliki nilai rata-rata yang lebih tinggi dari sebelum menggunakan stimulasi wicara. Setelah perhitungan selesai kemudian dilakukan uji signifikasi yaitu dengan cara membandingkan antara thit yang di peroleh dan tab. Dengan kriteria jika harga $t_{\text {hitung }}<t_{\text {tabel}}$, maka $\mathrm{H}_{0}$ diterima dan $\mathrm{H}_{\mathrm{a}}$ ditolak, dan jika harga thitung > ttabel maka $\mathrm{H}_{0}$ ditolak dan $\mathrm{H}_{\mathrm{a}}$ diterima. Pada taraf signifikansi $5 \%$ dengan dk $\mathrm{n}-1$. Data tersebut menunjukan bahwa $t_{\text {hitung }}>t_{\text {tabel }}$, dimana harga $t_{\text {hitung }}=28,29$ dan $t_{\text {tabel }}=2,228$, maka $H_{0}$ ditolak dan $\mathrm{H}_{\mathrm{a}}$ diterima, pada taraf signifikansi $5 \%$ dengan $\mathrm{dk}=\mathrm{n}-1$. Jadi data tersebutmenunjukan bahwa stimulasi wicara berpengaruh terhadap kemampuan berbahasa aanak tunarungu usia dini TK Tunarungu Sushrusa Denpasar Tahun Ajaran 2018/2019.

\section{DAFTAR PUSTAKA}

Asmariani, A. (2016). Konsep Media Pembelajaran Paud. Al-Afkar: Jurnal Keislaman \& Peradaban, 5(1). https://doi.org/10.28944/afkar.v5i1.108

Bayu Pramartha, N. (2012). Sociedad de control y profesión docente. Las imposturas de un discurso y la exigencia de una nueva realidad. Antimicrobial Agents and Chemotherapy, 53(95), 45-52. https://doi.org/10.1017/CBO9781107415324.004

Maimum. (2016). Evaluasi Program Parenting Pada Pendidikan Anak Usia Dini (PAUD) Di Kota Mataram, 168-201. Retrieved from journal.unj.ac.id/unj/index.php/jtp/article/download/5368/3995/

Masitah, W. (2016). Meningkatkan Kemampuan Bahasa Melalui Metode Bercerita Dengan Menggunakan Media Audio Visual Di Kelompok B RA Saidi Turi Kecamatan Patur Batu Kabupaten Deli Serdang., 8, 120-146. https://doi.org/https://doi.org/10.30596/intiqad.v8i2.733

Pebriana, P. H. (2017). Pengaruh Musik dalam Mengembangkan Kemampuan Mengenal Bilangan Siswa Kelompok A di TK Lintang Surabaya. Jurnal Obsesi : Jurnal Pendidikan Anak Usia Dini, 1(2), 131. https://doi.org/10.31004/obsesi.v1i2.25

Rahmaniar. (2015). Bagi Anak Tunarungu-Wicara Tingkat Tklb Di Slb-B ( Tunarungu ) Rahmaniar Bagi Anak Tunarungu-Wicara, 1-25.

Salis Qoimudin, I. (2016). Peningkatan Keterampilan Artikulasi Melalui Pendekatan Visual, Audiotori, Kinestetik, Taktil ( VAKT) Pada Anak Tunarungu Kelas Dasar II Di SLB Wiyata Dharma 1 Tempel, 23(45), 5-24.

Sardjono. (2014). Terapi Wicara. Jakarta: Dapertemen Pendidikan Nasional.

Silayusa, N. P. (2015). Pengaruh Metode Pembelajaran Problem Solving Berbantuan Media Audio Terhadap Motivasi Belajar Dan Prestasi Belajar Ips Siswa Smalb Di Slb a Negeri Denpasar. Jurnal Ilmiah Pendidikan Dan Pembelajaran Ganesha, 5(1), 1-11.

Soemantri, S. (2012). psikologi anak luar biasa. bandung: PT.Refika Aditama.

Sugiyono. (2017). Metode Penelitian Pendidikan. Bandung: Alfabeta.

Wasita, A. (2013). Seluk-Beluk Tunarungu \& Tunawicara Serta Strategi Pembelajarannya. Jogjakarta: Javalitera.

Yuliana, S., R, S. D., Pertiwi, A., S, D. P., \& Indonesia, U. P. (2017). Asesmen bahasa anak pre school (, 375-380. 